\title{
Working Capital without Money: A Furniture Craftsman Phenomenon in Sukorejo Bojonegoro
}

\author{
Hesty Hertikawati ${ }^{1}$, Agung Winarno ${ }^{2}$, Subagyo ${ }^{3}$ \\ 1, 2, 3 (Faculty of Economics, Universitas Negeri Malang,, Indonesia)
}

\begin{abstract}
This research focuses on identifying the meaning of working capital for craftsmen, the way they manage it and its benefit. Descriptive qualitative method with Miless and Huberman's model of data analysis is employed in this research [9]. Data is collected through interview, observation, and documentation. The result showed that the craftsmen sees working capital as money used for work and it meets the daily need of the business. Working capital components are workers, the level of customer trust, and money. Craftsmen only produce furniture for order, and rely on advance moneyfortheir working capital. To hire employees, craftsmen take the money from the settlement of the furniture when it is sent to the customer.Employees must work quickly so that orders can be delivered on time, and once delivered, they immediately got wages. In managing working capital, craftsmen do not put the money for business and self-need separately.
\end{abstract}

Keywords - Management of Working Capital, Furniture Craftsmen, Small and medium enterprise (SME)

\section{Introduction}

Small and medium enterprise (SME) is a type of business that has a major role in the national economy moreover for people's lives. SME has been able to become a source of income for the community and to absorb a lot of labor. SME develops very fast every year, and it also happens in Bojonegoro. The number of SME in this regency reaches up to 75.482 units (Department of Cooperative and UMKM, Bojonegoro Regency). They produce various featured products, some of which are Sentra Industri Mebel in Sukorejo Bojonegoro. The production process of SME cannot run smoothly without adequate capital. "The management of working capital is one of the most important aspects of the overall financial management practices of any organization" [1]. In line with the above statement, Bramasto cited in Sufiana and Purnawati also states that the capital is a major aspect that will support the operations of the company in achieving its goals [17]. A business will not run without capital. It needs maximum attention to the sources and the uses of capital, so that capital can be effectively managed and able to make profits for the business carried on.

Working capital management in a business needs to be noticed,for it concerns with its continuity. S.C Kuchhlal cited in Matarneh argues that "working capital is a business enterprise may be Compared to the blood of the human body" [8]. Like blood in the human body, working capital becomes power source that can run a business. A study conducted by Berryman (1983) cited in Agyei \& Mensah states that "poor" or "careless" working capital management is a major cause of SME failure [1]. In Rajasthan, it is estimated that about $40 \%$ of SSI units are sick industries. A large number of SSIS are found to be sick due to lack of working capital, raw materials and marketing facilities [8]. A research conducted by the Sunday mentions "Several SME in Nigeria fail a little time after they started, most fail due to poor financial management especially the working capital management" [18].

The fact that SME has a big role in the economy of a country, its working capital management needs serious attention in order not to fail. Not being Able to maintain a satisfactory level of working capital, it is Likely to become insolvent and may even be forced into bankruptcy [13]. Working capital is required to finance the company's operations [16]. If it is unavailable, the company is not able to run the daily operations. Working capital in the business should be sufficient in the sense that it is able to finance expenditures or company's everyday operations, because the sufficient working capital is profitable for the company [11]. However, the amount of working capital should not be too big or too small. Working capital which exceeds the company need shows the unproductive fund management and would impede the opportunity to earn profit. On the contrary,the inadequate working capital will lead to the disruption of activities and operation of the company [12].

Craftsmen in Sukorejo manage working capital under the principle of pokoknya jalan (above all the business can run). Craftsmen's understanding upon financial management is still lack, so that they never record every transaction that has been done. As a result, when a shortage of working capital is found, it cannot be anticipated.The amount of benefit also cannot be clearly identified. Craftsmen only produce furniture by order, because they did not have enough money to mass produce. Craftsmen use only the advances from customers as working capital. This research is important to do, because this study tried to reveal how craftsmen interpret and manage working capital as well as profits. The details of the current research focus are as follows: (1) to know the meaning of working capital for furniture craftsmen in Sukorejo Bojonegoro; (2) to discover how craftsmen 
furniture in Sukorejo Bojonegoro manage working capital for their business operations; and (3) to discover how craftsmen furniture in Sukorejo Bojonegoro manage profits obtained from the furniture sale.

\section{Research Methodology}

The research design chosen was a qualitative study with the type of case study. It is aimed at exploring, understanding and knowing the meaning of working capital for craftsmen, the way they manage working capital owned and the way they manage the benefit. Data was collected through in-depth interviews, observation and documentation. Data analysis employs Milles and Huberman's model, where the activities include making condensation, data presentation, and conclusion [9].

\section{Finding and Discussions}

\section{The Meaning of Working Capital for Furniture Craftsmen in Sukorejo Bojonegoro}

Regarding with the meaning of working capital for the craftsmen, the study found that craftsmen see working capital in their business as the money used to work and to meet the needs of everyday business. Components of working capital for the craftsmen include workers, the level of customer trust and money.

1.1. Worker

Craftsmen see workers as working capital because workers are important factors of production to the business. Without the workers, the business will find difficulty to proceed the production. As stated by Barney in Marimuthu, Ariokasamy, and Ismail (2009) that "human resource input plays a significant role in enhancing firm competitiveness [7].

Most craftsmen in Sukorejo has 20 workers. In an effort to hire employees, they take the money from the settlement of the finished furniture shipped to the customer. The faster the furniture can be sent, the sooner craftsmen obtain additional capital. Workers must work quickly so that orders can be delivered to customers on time, so workers could soon get his wages.

The role of workers in SMEs is very influential. If there are no workers, it is difficult to carry out the business production activities. That is why craftsmen consider their workers as working capital.

When linked to the function, working capital is able to generate revenue (income), either for the current period (current income) or future (future income). In this case the worker used as working capital to generate the current revenue and the next period because workers not only contribute in one term but during the business production process.

It is in line with the functional concept of working capital which bases the functions of the fund in generating revenue (income). Any fund used in the company is for the purpose of generating revenue. There is some fund used during the accounting period can immediately generate income for the period (current income) and there are also some used during the accounting period but not entirely produce current income, but some of it generates revenues for subsequent periods (future income) [2] [15] [4].

1.2. The Level of Customer Trust

Customer trust has such great value for the craftsmen. It is very important because craftsmen can get the funds for working capital purposes from it. If they are already trusted by customers, the working capital in the form of money will come by itself. For example, a customer already has great trust in the craftsmen that the work can be well done, he/she will most likely send some money to pay off the ordered furniture. For customers whose trust level is still low, they usually give advance only. This is an advantage for craftsmen because they can buy raw materials in cash without having debts to suppliers.In addition,they can also meet the needs of other businesses.

The rapid development of technology today eases the customers who want to order the goods. They do not have to come to the craftsmen. Here the trust between craftsmen with customers is needed. Customers who already believe the craftsmen would not hesitate to immediately transfer the fund so that the itcan be used by craftsmen as working capital.

\subsection{Money}

Money is a crucial point for any business expenses.Every monthly outcome such as the need to buy raw materials, to pay monthly bills, to pay the wages of workers and others require money. Without money, the business would be difficult to run. Proverb says "cash is the lifeblood of business" [14]. The rapid business development makes the entrepreneurs more creative in managing the availability of cash in the business. In this case, craftsmen utilize advances from customers for initial capital in working order and to meet the needs of their business.

"A working capital is the cash available for the transaction of day to day activities and also for unplaned and uexpexted expenses within the organization"[14]. In fact, advances alone are not sufficient to meet the entire needs of business. Craftsmen sometimes cannot afford to buy raw materials to make furniture. In such problems, craftsmen must owe the supplier of wood so that activity can still be executed. Craftsmen have to set up and maintain the balance of cash flow of the company in order for the cash outflowsnot to exceed the 
company's cash inflows. To get around in order to avoid any shortage of working capital, they regulate working time carefully. They provide target to workers to complete orders faster to immediately obtain additional capital from the repayment of furniture. Before the first order is completed,other orders are usually found from other customers so that craftsmen can play the working capital of the cycle. Craftsmen also control every expenditure made in order not to overdo,because the cash inflows and outflows will occur continuously as long as the company is able to operate. Craftsmen in Sukorejo still mix their privately owned money with company money. Craftsmen there also have not made the slightest financial records. They just rely on their limited memory to analyze revenue received and other expenditures made. As a result, gains or losses in business cannot be certainly known because there is no record at all.

\section{The Management of Working Capital by Furniture Craftsman in Sukorejo Bojonegoro}

Working capital is capital used for work to meet daily need in a business. Working capital in Sukorejo craftsmen is gained from customer advances, the profits of the previous period, and the receivables. These findings are somewhat different from the views of Jumingan that working capital may come from net income, gains from the sale of marketable securities, sales of fixed assets, the sale of stocks and bonds, loans from banks and credit of creditors [3].

The owned working capital is then managed by craftsmen so that the needs of the business can be fulfilled. The findings show that there are two ways practiced by craftsmen in managing working capital, managing the delivery time of goods and taking advantage of fixed assets owned by the company.

2.1. The Source of Working Capital

\subsubsection{Advances from customers}

Advance is used as the first source of working capital for the craftsmen because it is required to be fulfilled by customer once ordering furniture if they want the order processed. The amount of advance to pay is not determined by craftsmen. However, in most cases, customers made payment about $20-30 \%$ of the total price of the orderedfurniture.

The received advance is used to buy raw, supporting, orconsumable materials such as varnish, wood paint, paint thinner, nail and others

2.1.2. The profit from the previous period

The second source of working capital of craftsmen in Sukorejo is derived from the previous period. This is in line with the statement conveyed by Ahmad (1997: 99) cited in Yuyun (2009) that the presence of gain or profit from the company's operating profit and if it is not taken by the owner, it will increase the capital of the company [5].

One of profit made by craftsmen is managed to be working capital. The profit might be in the form of goods and cash. The goods one is in the form of wood waste (raw material) from the previous production. The residual wood can be reused as raw material for the next orders. So, the rest of the wood is not wasted and are still able to generate income if processed again. Further gains are in the form of money.Money from this advantage was deliberately been allocated by craftsmen to help sustain the needs of the business. This money is used to finance the needs of businesses that cannot be fulfilled from customer advances.

\subsubsection{Receivables}

Credit sales made by craftsmen causes receivables in their business. Generally, customers who buy on credit will settle payment when the order has been sent to the customer's place. Cash inflows from receivables may be used to meet the needs of short-term business. As presented by Mishra et al that the short-term obligations of the firm can be met only when there are sufficient liquid assets [10].

If the craftsman is able to deliver the orders in a short time, the cash inflow also remains faster, so the risk of shortage of working capital can be minimized. This is consistent with the statement of Jumingan that higher receivable turnover is better because it the invested working capital which is in the form of receivables would be lower [3].

2.2. Working Capital Management

Referring to the finding that the way craftsmen manage their working capital is through adjusting the time of delivering orders and leveraging assets held.

2.2.1. Managing the time for delivering orders

Craftsmen arrange furniture production time to consider the unwanted factors that may have occurred in the process of making furniture, such as the absenceof workers, the broken machine, the lack of supporting materials and others. These small things should also be considered because it could affect the timing of completion of furniture products. Craftsmen regulate the production time to time so that delivery of orders could reach the hands of customers in a time.

The timing of the delivery of orders has been implemented well by craftsmen, so that the cash inflows from the sale of the furniture can be predicted. They determine the length of the production process 
until the time of delivery of the goods in a way that is quite unique. They do it by feeling. Taking the lessons from quite long experience in the business of furniture, they can guess how long it takes to produce customer orders. The right timing of the delivery of orders can have an impact on the rapid acquisition of cash from the receivables. If they obtain repayment from the customer directly, they can also increase the working capital of the company.

Craftsmen have an attempt to maintain the continuity of cash inflows from the receivables. They do it by setting a target of delivering the goods. Their target is to be able to send the order at least once a week. So there are four times of delivery a month. Accounts receivable turnover in this business occurred about four times a month. It is great for a business because it can increase the productivity, and the money in the company can also be maintained so it minimizes the shortage of working capital in the business.

\subsubsection{Leveraging assets hold}

Craftsmen must have a number of fixed assets in their business, such as the place of production, vehicles, machineries, gallery and others. They can take advantage of the fixed assets to minimize the costs incurred that working capital expenses can be reduced, such as utilizing owned vehicles to transport teak from log parksto the premises so that the craftsmen do not need to spend the cost of transport. Besides, the owned fixed assets can also be used to supplement existing working capital,such as a large sawing machine.Craftsmen can take advantage of the machine to open the services of saws for other craftsmen who do not have chainsaws. In addition to to help other surrounding craftsmen, the service can also generate additional revenue for the company beyond selling products.

2.3. Profit Management by Furniture Craftsmen in Sukorejo Bojonegoro

The findings indicate that the advantage obtained from the sale of furniture is used to support the continuity of the furniture business in the future. The advantage is managed through using the money to buy teak or making it working capital again. The rest of the money from the purchase of teak is then deposited into a checking account as a reserve fund, and are used to increase fixed assets.

This finding is supported by the statement of Mamnun that even though the business profits is not that much, if managed professionally, it will be a tremendous potential to develop a business or a business that is being managed [6]. The management of these benefits must be done to maintain the existence of the business. Efforts made by furniture craftsmen in Sukorejo in managing advantages are as follows:

\subsubsection{To be used for another working capital}

Furniture craftsmen in Sukorejo utilize the benefits of the first company's operating results another working capital.The step taken is using the money to buy teak. Teak is the first priority for craftsmenbecause teak is the main raw material of furnituremanufacture.If they experienced delays in obtaining teak then it will hamper the company's production process. So they always prioritize buying teak whenever they have a little more money although at that time they did not have order.If they have benefit from the sale of furniture, the first thing to do is to invest these profits by buying teak. This is in accordance with the views of Mamnun [6] that the management of profits obtained by a company is used for another capital.

2.3.2. To be used for reserved fund

Another effort made by craftsmen in managing their advantage is to deposit the rest of the profits into the company's account. Profit included in this account is actually used as the company's reserved fund. Craftsmen in Sukorejo prefer to keep the money from his business profits in the company's account. Because they will feel more secure and if at any time there is a shortage of working capital, or there is something urgent, the reserved fund will be used.

This condition is also in accordance with the opinion expressed by Mamnun that the management of the company's profit is by making the business profits reserved fund [6]. According Mamnun, the amount of profit that is used as reserved fund is equal to $20 \%$ of the profits [6]. However, the amount of advantages deposited by craftsmen is not definite, because the deposited profit is also adjusted to the purchase of teak because the purchase of teak is the main priority in the management of advantages.

2.3.3. To develop the business

Some benefits of the company's operation may be set for the purpose of business development. According to the theory of business development, the benefit can be used for developing infrastructure, improving the quality of human resources, improving IT systems, and expending business by opening new branches. The advantage for business development is done by collecting profits into an account as in point 2 above. So, in addition to the business, profit is used as reserved fund of corporation in case at any time they have difficulty finding working capital.The money deposited in the account is expected to gradually increase so that they can develop their business. 
Business development can be done by increasing the number of fixed assets such as machinery with larger capacity, buying vehicles as a means of transporting goods, building a showroom, and building production place in order for the company's production increases.

\section{Conclusion}

\section{Conclusion and Suggestion}

1.1. The interpretation of working capital delivered by craftsmen tends to be based on the experience or feeling perceived by craftsmen during running of the business. Working capital is defined as money used for work and it meets the needs of everyday business. The components include workers, level of customer trust and money.

1.2. In managing the working capital, the craftsmen mostly finance the production by relying on advances from customers. Wages of workers is given after the settlement of the customer.

1.3. Profit derived by craftsmen is used systematically to support the continuity of business, but unfortunately all the efforts are not supported with detailed financial records so that the amount of benefits and the amount of working capital needs in the business cannot be calculated in advance.

\section{Suggestion}

2.1. For Craftsmen: Craftsmen are supposed to be aware of the importance of financial records in the business, so that the financial condition can be clearly identified about the amount of income and expenditure. Craftsmen also need to learn to separate the personal money with that of company in order for finance of the company can be controlled.

2.2. For the Government in Bojonegoro: The Government, through the Department of Cooperatives and SMEs or Disperindag, is supposed to cooperate with the banks to hold more frequent trainings on financial management in small businesses. Due to the rapid developments of the business, craftsmen should also be trained about the manner of managing business finances and procedures for financial records in small business.

[1] Agyei, B.K \& Mensah, Working Capital Management Practices of Small Firms in the Ashanti Region of Ghana, International Journal of Academic Research in Business and Social Sciences, 2 (1), 2012.

[2] Halim, A. \& Sarwoko. 2008. Manajemen Keuangan (Dasar-Dasar Pembelanjaan Perusahaan) Buku 1: Manajemen Dan Analisis Aktiva. Yogyakarta: BPFE.

[3] Jumingan, Analisis Laporan Keuangan (The Analysis of Financial Report), (Jakarta: Bumi Aksara, 2009)

[4] Kasmir, Analisis Laporan Keuangan (The Analysis of Financial Report), (Jakarta: PT. Raja Grafindo Persada, 2012)

[5] Laila, N.Y. 2009. Analisis Pengelolaan Modal Kerja Untuk Meningkatkan Produktivitas Perusahaan (Study Pada PT. Indocement Tunggal Prakasa Tbk). Fakultas Ekonomi Universitas Maulana Malik Ibrahim Malang.

[6] Mamnun, T., 4 Pokok Pengelolaan Profit Bisnis Agar Terus Berkembang (The Main Management of Business Profit in order to develop continuously), (https://www.maxmanroe.com/4-pokok-pengelolaan-profit-bisnis-agar-terus-berkembang.html), 2015.

[7] Marimuthu, M., Arokiasamy, L. \& Ismail, M., Human Capital Development and Its Impact On Firm Performance: Evidence From Developmental Economics, The Journal Of International Social Research, 2 (8), 2009.

[8] Matarneh, B., Working Capital Management of Small Scale Industries in Rajasthan, International Journal of Financial Research, 3 (2), 2012.

[9] Miles, M.B., Michael H. \& Jhonny S., Qualitative Data Analysis-Third Edition, (London: Sage Publication Ltd, 2014).

[10] Mishra, P., Rajpoot, S \& Sharma, N., A Study of Working Capital Management in Small Scale Industries, International Journal of Management (IJM), 7 (3), 2016, 266-278.

[11] Munawir, S., Analisis Informasi Keuangan (The Analysis of Financial information), (Yogyakarta: Liberty Yogyakarta, 2002)

[12] Mursalini, W.I., Anaisis Pengaruh Perputaran Modal Kerja Terhadap Profitabilitas Perusahaan Pada CV. Business Ali Solok (The Analysis of Working Capital Turnover towards the Company Profitability in CV. Business Ali Solok), 2012.

[13] Muya, T.W \& Gathogo, G., Effect Of Working Capital Management On The Profitability Of Manufacturing Firm In Nakuru Town, Kenya, International Journal of Economic, Commerce, and Management, 4 (4), 2016.

[14] Nicholas, A.K., Small ScaleBusiness Practice of Basic Financial Management with Regard to Liquidity, International Journal of Research In Social Siences, 4 (5), 2014.

[15] Riyanto, B. 2008. Dasar-dasar Pembelanjaan Perusahaan Edisi 4. Yogyakarta: BPFE.

[16] Sartono, R.A., Manajemen Keuangan Teori dan Aplikasi Edisi Empat (Financial Management Theory and Application, The $4^{\text {th }}$ edition), (Yogyakarta: BPFE, 2012)

[17] Sufiana, N. \& Purnawati, N.K., Pengaruh Perputaran Kas, Perputaran Piutang dan Perputaran Persediaan Terhadap Profitabilitas (The Influence of Cash, Receivables, and Stock Turnover towards Profitability), Journal of Economic Faculty, Unud, 2011, 451467.

[18] Sunday, K.J. Effective Working Capital Management in Small and Medium Scale Enterprises (SMEs), International Journal of Business and Management, 6 (9), 2011. 